\title{
PERLINDUNGAN KONSUMEN DALAM TRANSAKSI ELEKTRONIK
}

\author{
Rizka Syafriana \\ Fakultas Hukum Universitas Muhammadiyah Sumatera Utara \\ Email: rizkasyafriana11@gmail.com
}

\begin{abstract}
Consumer protection is a matter of human interest, therefore, a hope for all nations in the world to be able to make it happen. In Indonesia obstacles that hinder the development of trade via the Internet is in inadequate facilities that are needed for electronic dispute resolution institutions to cope.
\end{abstract}

Kata Kunci: Konsumen, Transaksi Elektronik, E-Commerce.

\section{A. Latar Belakang}

Istilah hukum konsumen dan hukum perlindungan konsumen sudah sangat sering terdengar. Namun belum jelas benar apa saja yang masuk kedalam materi keduanya. Karena posisi konsumen yang lemah maka ia harus dilindungi oleh hukum. Salah satu sifat, sekaligus tujuan hukum itu adalah memberikan perlindungan (pengayoman) kepada masyarakat, sehingga hukum konsumen dan hukum perlindungan adalah dua bidang hukum yang sulit dipisahkan dan ditarik batasnya.

Ada juga yang berpendapat, hukum perlindungan konsumen merupakan bagian dari hukum konsumen yang lebih luas itu. Az. Nasution, misalnya berpendapat hukum perlindungan konsumen merupakan bagian dari hukum konsumen yang memuat azas-azas atau kaidah-kaidah bersifat mengatur, dan juga mengandung sifat yang melindungi kepentingan konsumen. Adapun hukum konsumen diartikan sebagai keseluruhan azas-azas dan kaidah-kaidah hukum yang mengatur hubungan dan masalah antara berbagai pihak satu sama lain berkaitan dengan barang dan atau jasa konsumen, di dalam pergaulan hidup (AZ Nasution 1995: 64-65).

Pasal 1 UUPK 1999 mengatur mengenai perlindungan konsumen. Namun, pada kenyataannya UUPK 1999 belum sepenuhnya mengatur mengenai transaksi 
elektronik, hanya beberapa pasal saja yang dapat dipergunakan dalam transaksi elektronik. Hal tersebutlah yang membuat masih kurangnya perlindungan bagi konsumen yang melakukan transaksi elektronik. Teknologi informasi dan telekomunikasi telah memasuki berbagai segmen aktivitas manusia, baik dalam sektor politik, sosial, budaya, maupun ekonomi dan bisnis. Dalam bidang perdagangan, teknologi juga dapat dimanfaatkan sebagai media aktivitas bisnis terutama karena kontribusinya terhadap efisiensi. Aktivitas perdagangan melalui media internet ini populer disebut electronic commerce (e-commerce) atau disebut juga dengan transaksi elektronik (A.M. Wibowo 2009: http://www.geocities. com).

Perdagangan elektronik merupakan model transaksi dengan karakteristik yang berbeda dengan model transaksi konvensional, apalagi dengan daya jangkau yang tidak hanya lokal tapi juga bersifat global. Metode baru tersebut mampu menghasilkan bisnis secara langsung ataupun sering disebut online. Melalui transaksi perdagangan ini, konsep perdagangan yang telah ada dapat berubah menjadi konsep telemarketing, yaitu perdagangan jarak jauh dengan menggunakan internet (Dikdik M. Arief Mansur 2005: 144). Selain itu, dengan konsep tersebut dapat diketahui kualitas dan kuantitas barang dan jasa yang diinginkan meski secara virtual dan tanpa dibatasi oleh wilayah. Hal tersebut mengakibatkan perilaku konsumen menjadi semakin kritis dan selektif dalam menentukan produk yang akan dipilihnya, terutama dengan adanya kemudahan yang diberikan dalam transaksi perdagangan elektronik seperti halnya transaksi konvensional. Daya tarik ini juga yang mulai menarik minat konsumen untuk melakukan transaksi perdagangan elektronik.

Mengenai masalah penyelesaian sengketa dalam transaksi elektronik memiliki kecendrungan memilih forum arbitrase. Hal ini untuk menjaga reputasi para pihak yang bersengketa karena putusan forum arbitrase bersifat final dan mengikat serta dianggap sesuai dengan semboyan transaksi elektronik yaitu murah, efisien dan praktis sebagaimana dikemukakan Ester Dwi Maghfirah dalam tulisannya berjudul Perlindungan Konsumen Dalam Transaksi Elektronik, dalam http://www.students.ac.id. Pada bagian Penjelasan UU No. 11 Tahun 2008 tentang 
Informasi dan Transaksi Elektronik disebutkan bahwa Pemerintah mendukung pengembangan Teknologi Informasi melalui infrastruktur hukum dan pengaturannya, sehingga pemanfaatan Teknologi Informasi dilakukan secara aman untuk mencegah penyalahgunaannya dengan memperhatikan nilai agama dan sosial budaya Indonesia, dalam undang-undang ini menjelaskan tentang transaksi elektronik dan penyelesaian sengketa.

Bentuk perdagangan ini juga dapat mengakibatkan kerugian pada konsumen, hal ini disebabkan oleh adanya beberapa perjanjian yang menyatakan pengalihan tanggung jawab pelaku usaha. Selain itu, masih lemahnya perlindungan hukum pada perdagangan elektronik, atas dasar tersebut diperlukan jaminan keamanan perdagangan elektronik untuk menumbuhkan kepercayaan, terutama pada pihak konsumen, bisnis yang demikian tentu saja akan dihadapkan dengan berbagai masalah perlindungan konsumen, khususnya keabsahan transaksi yang menggunakan media elektronik.

Teknologi internet mempunyai pengaruh yang sangat besar terhadap perekonomian dunia. Internet membawa perekonomian dunia memasuki babak baru yang lebih populer dengan istilah digital economic atau perekonomian digital. Makin banyak kegiatan perekonomian dilakukan melalui media internet, misalnya perdagangan yang semakin banyak mengandalkan e-commerce sebagai media transaksi. Berdasarkan uraian ini, maka dapat dikatakan bahwa penting sekali untuk mengemukakan perlindungan terhadap transaksi elektronik sehingga perlu dilakukan kajian yang bertujuan untuk mengetahui perlindungan konsumen dalam transaksi elektronik.

\section{B. Metode Penelitian}

Jenis penelitian hukum dapat dibedakan menjadi penelitian hukum normatif dan penelitian hukum empiris/sosiologis. Penelitian hukum normatif merupakan penelitian yang datanya bersumber pada data sekunder dan berhubung data penelitian ini adalah data sekunder, maka termasuk dalam jenis penelitian hukum normatif. Sifat penelitian ini adalah deskriptif, yang bertujuan untuk memberikan gambaran tentang gejala-gejala sosial yang terkait dengan 
perlindungan konsumen dalam transaksi elektronik. Sumber data penelitian berupa bahan hukum primer, bahan hukum sekunder dan bahan hukum tersier. Metode pengumpulan data dilakukan menggunakan teknik studi dokumen, yang dianalisis dengan menggunakan teknik analisis kualitatif.

\section{Hasil Penelitian dan Analisis}

\section{Ciri dan ruang lingkup transaksi elektronik}

Berdasarkan hasil penelitian diketahui bahwa mekanisme transaksi elektronik tidak seperti transaksi jual beli konvensional karena setiap transaksi elektronik diawali dengan tahap penawaran melalui media internet oleh pelaku usaha, tahap penerimaan oleh konsumen, tahap kesepakatan antara para pihak, tahap pembayaran melalui jasa perbankan, dan diakhiri dengan tahap pengiriman produk yang dipesan melalui jasa ekspedisi. Dalam praktiknya, Undang-undang Nomor 9 Tahun 1999 tentang Perlindungan Konsumen (UUPK) belum sepenuhnya melindungi konsumen dalam transaksi elektronik.

Kondisi tersebut karena UUPK belum mengatur mengenai implementasi lebih lanjut pengertian perlindungan konsumen yang mencakup perlindungan konsumen online, hak atas informasi yang harus diberikan kepada konsumen melalui media online untuk mencegah terjadinya tindakan curang, penyalahgunaan kartu pembayaran milik orang lain, tanggung jawab pelaku usaha yang mencakup tanggung jawab ISP (Internal Service Provider), beban pembuktian elektronik, dan penyelesaian sengketa melalui sarana tehnologi informasi. Mengenai masalah penyelesaian sengketa dalam transaksi elektronik memiliki kecendrungan memilih forum arbitrase.

Suatu perjanjian adalah semata mata suatu persetujuan yang diakui oleh hukum. Persetujuan ini merupakan kepentingan yang pokok dalam dunia usaha, dan menjadi dasar dari kebanyakan transaksi dagang (Abdul Kadir Muhammad 2006: 93). Perjanjian yang dinyatakan sah adalah suatu perjanjian yang memenuhi empat syarat yang terdapat dalam Pasal 1320 KUHPerdata, yaitu:

a. Adanya kesepakatan kedua belah pihak;

b. Kecakapan untuk melakukan perbuatan hukum; 
c. Adanya objek tertentu, dan

d. Adanya sebab yang halal.

Perdagangan elektronik (e-commerce) menentukan kesepakatan antara para pihak dinyatakan secara langsung menggunakan media internet. Pihak-pihak dapat kesepakatannya dengan jalan memilih tombol setuju (agree) pada perjanjian internet ataupun secara langsung mengirim konfirmasi persetujuannya melalui $e$ mail. Kesepakatan pada kontrak e-commerce berbeda dengan kontrak biasa yang umumnya disetujui dengan pembubuhan tanda tangan bersama. Kesepakatan dalam kontrak e-commerce dinyatakan secara elektronik pula. Dalam wawancara dengan Mariam Darus Badrulzaman berkenaan dengan persetujuan secara elektronik dikatakan bahwa : "dengan memilih tombol setuju ataupun menyatakan konfirmasi kesepakatan melalui e-mail tersebut telah menyatakan sepakat" (Jun Cai 2002: 45).

Ciri ciri dari perdagangan yang dilakukan melalui media elektronik sebagai berikut (Mariam Darus Badrulzaman dkk, 2004: 287):

a. Cara Komunikasi. Kedua belah pihak harus memperhatikan bahwa situs untuk memberikan informasi untuk hal yang tidak pantas (ilegal). Dalam kebanyakan perjanjian dengan internet service provider atau di dalam perjanjian standar terdapat klausul bagi klien untuk tidak menggunakan situs yang melanggar ketertiban umum, pelanggaran terhadap karya-karya yang dilindungi undang-undang hak milik intelektual, mengadakan pengumuman yang menyesatkan, menyebarkan dokumen yang terlarang, bertindak melawan peraturan internasional yang terkait.

b. Garansi dan vrijwaring. Bahwa di dalam kontrak tersebut harus dinyatakan jaminan yang harus dibuat oleh pengembang webside atau hasil karya yang dibuat yang harus bebas dari unsur penjiplakan, memperhatikan hak intelektual dan tidak melanggar ketentuan hukum yang ada.

c. Biaya. Para pihak dapat mengadakan kesepakatan bahwa kewajiban untuk membayar ganti rugi dilakukan dengan pembagian resiko (risk sharing). 
d. Pembayaran. Mengenai harga dan cara pembayaran apakah pembayaran sekaligus, kredit, ataupun berdasarkan jumlah tertentu dari tugas yang telah diselesaikan.

e. Kerahasiaan. Dalam hal ini perlu dibuat untuk memastikan agar pengembangan terikat untuk menjaga segala kerahasiaan informasi yang terdapat di dalam kontrak/perjanjian.

f. Kaitan dengan hak milik intelektual. Kepemilikan dari perangkat lunak untuk menciptakan dan mendesain webside tersebut terkait dengan peraturan hak milik intelektual yang digunakan.

g. Pengumuman. Agar webside mempunyai kemampuan untuk melampaui batasbatas yurisdiksi nasional oleh karena itu kontrak-kontrak internasional yang terjadi dalam e-commerce harus mengandung pilihan hukum.

h. Perjanjian Campuran. Kontrak dagang merupakan perjanjian campuran, artinya mengandung kebebasan unsur yang dikenal oleh KUHPerdata, antara lain:

1) Perjanjian jual beli

2) Perjanjian pembuktian

3) Sewa

4) Kuasa

5) Lisensi.

Perdagangan melalui media elektronik memiliki beberapa karakteristik yang sangat khusus, yaitu:

a. Transaksi tanpa batas

Sebelum era internet, batas-batas geografis menjadi penghalang suatu perusahaan atau individu yang ingin go internasional. Sehingga hanya perusahaan atau individu dengan modal besar yang dapat memasarkan produknya keluar negeri. Dewasa ini dengan internet pengusaha kecil dan menengah dapat memasarkan produknya secara internasional cukup dengan membuat situs web atau dengan memasang iklan di situs-situs internet tanpa batas waktu (24 jam), dan tentu saja pelanggan dari seluruh dunia dapat mengakses situs tersebut dan melakukan transaksi secara online. 
b. Transaksi anonim

Para penjual dan pembeli dalam transaksi melalui internet tidak harus bertemu muka satu sama lainnya. Penjual tidak memerlukan nama dari pembeli sepanjang mengenai pembayarannya yang ditentukan, yang biasanya dengan kartu kredit.

c. Produk digital dan non digital

Produk-produk digital seperti software komputer, musik dan produk lainnya yang bersifat digital dapat dipasarkan melalui internet dengan cara mendownload secara elektronik. Dalam perkembangannya objek yang ditawarkan melalui internet juga meliputi barang-barang kebutuhan hidup lainnya.

d. Produk barang tidak berwujud

Banyak perusahaan yang bergerak dibidang e-commerce dengan menawarkan barang tak berwujud seperti data, software dan ide-ide yang dijual melalui internet.

\section{Kesepakatan pelaku usaha dan konsumen dalam transaksi elektronik}

Perjanjian yang dinyatakan sah adalah suatu perjanjian yang memenuhi empat syarat yang terdapat dalam Pasal 1320 KUHPerdata, yaitu:

a. Adanya kesepakatan kedua belah pihak;

b. Kecakapan untuk melakukan perbuatan hukum;

c. Adanya objek tertentu;

d. Adanya sebab yang halal

Syarat pertama dan kedua diatas yang dinamakan syarat subjektif, apabila salah satu dari kedua syarat tersebut tidak dapat dipenuhi, maka perjanjian dapat dibatalkan, sedangkan syarat ketiga dan keempat merupakan syarat objektif, maka apabila salah satu dari kedua syarat tidak dipenuhi, maka perjanjian batal demi hukum (Johanes Ibrahim dan Lindawaty 2005: 44).

Kesepakatan ini diatur dalam Pasal 1320 ayat (1) KUHPerdata, yaitu persesuaian pernyataan kehendak antara satu orang atau lebih dengan pihak lainnya, pernyataan kehendak antara dua orang atau lebih dengan pihak lainnya. Ada lima cara terjadinya persesuaian pernyataan kehendak, yaitu:

a. Bahasa yang sempurna dan tulisan; 
b. Bahasa yang sempurna secara lisan;

c. Bahasa yang tidak sempurna asal dapat diterima oleh pihak lawan, karena dalam kenyataannya seringkali seseorang menyampaikan dengan bahasa yang tidak sempurna tetapi dimengerti oleh pihak lawannya;

d. Bahasa isyarat asal dapat diterima oleh pihak lawannya;

e. Diam atau membisu, tetapi dipahami atau diterima pihak lawan.

Pada dasarnya, cara yang paling banyak dilakukan oleh para pihak, yaitu dengan bahasa yang sempurna secara lisan dan tulisan. Tujuan pembuatan perjanjian secara tertulis adalah agar memberikan kepastian hukum bagi para pihak dan sebagai alat bukti yang sempurna, dikala timbul sengketa di kemudian hari (Salim H.S. 2004: 33). Di dalam KUHPerdata tidak disebutkan secara jelas tentang momentum terjadinya kontrak. Pada Pasal 1320 KUHPerdata hanya disebutkan cukup dengan adanya konsensus para pihak. Menurut Mariam Darus Badrulzaman (2005: 24), dalam berbagai literatur disebutkan empat teori yang membahas momentum terjadinya kontrak, yaitu:

a. Teori kehendak (wilstheorie), mengajarkan bahwa kesepakatan terjadi apabila pada saat kehendak pihak penerima dinyatakan, misalnya dengan menuliskan surat.

b. Teori pengiriman (verzendtheorie), mengajarkan bahwa kesepakatan terjadi pada saat kehendak yang dinyatakan itu dikirimkan oleh pihak yang menerima tawaran.

c. Teori Pengetahuan (vernemingstheorie), mengajarkan bahwa pihak yang menawarkan seharusnya sudah mengetahui bahwa tawarannya diterima.

d. Teori penerimaan (vertrowenstheorie), mengajarkan bahwa kesepakatan itu terjadi pada saat pernyataan kehendak dianggap layak diterima oleh yang menawarkan.

Proses perdagangan eletronik (e-commerce) menentukan kesepakatan antara para pihak dinyatakan secara langsung menggunakan media internet. Pihak-pihak dapat kesepakatannya dengan jalan memilih tombol setuju (agree) pada perjanjian internet ataupun secara langsung mengirim konfirmasi persetujuannya melalui e-mail. Kesepakatan pada kontrak e-commerce berbeda 
dengan kontrak biasa yang umumnya disetujui dengan pembubuhan tanda tangan bersama. Kesepakatan dalam kontrak e-commerce dinyatakan secara elektronik pula.

\section{Penegakan hukum dalam proses perlindungan konsumen pada transaksi elektronik}

Perlindungan konsumen merupakan segala upaya yang menjamin adanya kepastian hukum untuk memberi perlindungan konsumen agar terwujudnya tujuan perlindungan konsumen di Indonesia (Endang Sri Wahyuni 2003: 91). Adanya Undang-undang Perlindungan Konsumen memberikan dampak ekonomi yang positif bagi dunia usaha, dunia usaha dipacu untuk meningkatkan kualitas/mutu produk barang dan jasa sehingga produknya memiliki keunggulan kompetitif di dalam dan luar negeri.

Di Indonesia, dalam UU ITE disebutkan bahwa transaksi elektronik dapat dituangkan dalam kontrak elektronik. Dalam kontrak elektronik tersebut dapat ditentukan pilihan hukum mana yang digunakan dalam menyelesaikan perselisihan (dispute). Jika pilihan hukum tidak dilakukan, maka yang berlaku adalah hukum yang didasarkan pada asas hukum perdata internasional. Begitupun dengan pilihan forum pengadilan mana yang berhak. Para pihak dalam transaksi e-commerce dapat menentukan forum pengadilan, arbitrase, atau lembaga penyelesaian sengketa alternatif lainnya mana yang dipilih dalam e-contract. Dan jika tidak dilakukan pemilihan forum, maka penyelesaian sengketa akan kembali pada asas dalam Hukum Perdata Internasional.

Cara-cara penyelesaian sengketa dapat ditempuh jika terjadi sengketa atau konflik yang bersumber dari adanya perbedaan pendapat atau ketidaksesuaian di antara para pihak. Apabila pihak-pihak tidak berhasil menemukan bentuk penyelesaian yang tepat, maka perbedaan pendapat ini dapat berakibat buruk bagi kelangsungan hubungan di antara keduanya. Oleh karena itu, setiap menghadapi perbedaan pendapat (sengketa), para pihak selalu berupaya menemukan cara-cara penyelesaian yang tepat. Persoalan ini tidak bisa diatasi hanya dengan upayaupaya di level nasional, dan jika ada masyarakat yang melakukan upaya hukum, mereka hanya diwajibkan menghitung kerugian yang diderita. Sementara yang 
membuktikan penyebab kecelakaan dan kesalahan yang terjadi adalah tanggung jawab pelaku usaha (http://hukumpositif.com).

Ketentuan Pasal 23 UUPK menyebutkan pelaku usaha yang menolak dan/atau tidak memberi dan/tidak memenuhi ganti rugi atas tuntutan konsumen dapat digugat melalui Badan Penyelesaian Sengketa Konsumen (BPSK) atau mengajukan ke badan peradilan di tempat kedudukan konsumen. Penyelesaian sengketa konsumen dapat ditempuh melalui pengadilan ataupun diluar pengadilan berdasarkan pilihan sukarela para pihak yang bersengketa (Pasal 45 UUP). Sehingga jika terjadi sengketa/konflik antara pelaku usaha dan konsumen dalam suatu perdagangan maka terdapat beberapa cara yang dapat membantu penyelesaian sengketa antara pelaku usaha dengan konsumen, proses penyelesaian sengketa tersebut adalah:

a. Melalui jalur pengadilan

Litigasi (melalui jalur pengadilan) pada umumnya akan menimbulkan suasana permusuhan yang dapat berkepanjangan bagi para pihak yang berperkara, litigasi untuk pelaku ekonomi atau masyarakat bisnis internasional juga membawa dampak lain, misalnya mengenai system hukum yang berbeda, penentuan tempat berlitigasi, hubungan bisnis yang menjadi buruk serta pertanyaan mengenai penegakan serta pelaksanaan keputusan. Di samping itu litigasi juga memerlukan waktu, biaya, ditambah dengan alasan teknis yaitu penumpukan jumlah perkara dipengadilan, maka peluang alternatif untuk penyelesaian sengketa sangat diperlukan (Ningrum Natasya Sirait 2008).

Sengketa-sengketa di Indonesia dan juga negara lainnya yang diajukan melalui jalur pengadilan (litigasi) ternyata memiliki beberapa kelemahan, di antaranya (Ahmad M. Ramli 2004: 56):

1) litigasi memaksa para pihak berada pada posisi yang ekstrim memerlukan pembelaan;

2) litigasi mengangkat seluruh persoalan dalam suatu perkara, sehingga mendorong para pihak untuk melakukan penyelidikan terhadap kelemahankelemahan pihak lainnya; 
3) proses litigasi memakan waktu yang lama dan memakan biaya yang mahal; dan

4) hakim seringkali bertindak tidak netral dan kurang mengikuti perkembangan ilmu pengetahuan yang mendasari penyelesaian suatu masalah hukum baru.

b. Alternatif penyelesaian sengketa

Penyelesaian sengketa melalui Alternative Dispute Resolution adalah penyelesaian sengketa atau beda pendapat melalui prosedur yang disepakati para pihak, yakni penyelesaian di luar pengadilan dengan cara konsultasi, negoisasi, mediasi, konsiliasi atau penilaian ahli (Ningrum Natasya Sirait 2008).

Usaha-usaha untuk menemukan bentuk penyelesaian sengketa alternatif terjadi pada saat Warren Burger (mantan Chief Justice) diundang pada suatu konferensi yaitu Roscoe Pound Conference on the Causes of Popular Dissatisfaction with the Administration of Justice (Pound Conference) di Saint Paul, Minnesota. Para akademisi, pengamat hukum, serta pengacara yang menaruh perhatian pada masalah sengketa/konflik berkumpul bersama pada konferensi tersebut. Beberapa makalah yang disampaikan pada saat konferensi, akhirnya disusun menjadi suatu pengertian dasar (basic understanding) tentang penyelesaian sengketa saat itu (Ningrum Natasya Sirait 2008).

Beberapa tahun berikutnya, penyelesaian sengketa alternatif (Alternative Dispute Resolution) mulai diterapkan secara sistematis. Hakim seringkali memerintahkan kepada para pihak untuk ikut berpartisipasi dalam suatu persidangan. Peraturan di pengadilan senantiasa mensyaratkan dalam hal ini hanya akan dibahas mengenai arbitrase, karena cara arbitrase yang sering digunakan di beberapa kontrak serta adanya kesamaan dengan proses pembuktian dalam badan peradilan biasa.para pihak untuk menyelesaikan kasus-kasus tertentu (seperti: malpraktek) diselesaikan melalui arbitrase, bahkan di beberapa pengadilan, pihak-pihak disyaratkan untuk mencoba terlebih dahulu menyelesaikan sengketa yang timbul diantara mereka melalui cara mediasi sebelum menempuh jalur pengadilan (www.accountingcommunity.blogspot.com).

Di Indonesia, dalam UU ITE disebutkan bahwa transaksi elektronik dapat dituangkan dalam kontrak elektronik. Dalam kontrak elektronik tersebut dapat 
ditentukan pilihan hukum mana yang digunakan dalam menyelesaikan perselisihan (dispute). Jika pilihan hukum tidak dilakukan, maka yang berlaku adalah hukum yang didasarkan pada asas hukum perdata internasional. Begitupun dengan pilihan forum pengadilan mana yang berhak.

Para pihak dalam transaksi e-commerce dapat menentukan forum pengadilan, arbitrase, atau lembaga penyelesaian sengketa alternatif lainnya mana yang dipilih dalam e-contract. Dan jika tidak dilakukan pemilihan forum, maka penyelesaian sengketa akan kembali pada asas dalam Hukum Perdata Internasional. Pilihan hukum dalam kontrak komersil selalu menjadi kontroversial (http://teguharifiyadi.blogspot.com). Dari hasil penelitian menunjukkan bahwa umumnya konsumen itu segan berperkara, apalagi apabila biaya yang dikeluarkan lebih besar dari kemungkinan hasil yang akan diperoleh . Hal itu pula yang terjadi dalam transaksi e-commerce. Dalam transaksi e-commerce, karakteristik perkara yang muncul dalam perlindungan konsumen lebih kompleks dibanding transaksi nyata. Persoalan yurisdiksi dan pembuktian dapat menjadi hambatan dan pertimbangan konsumen untuk mengajukan gugatan.

Di Indonesia, proses pemeriksaan sengketa dalam suatu perdagangan elektronik dilakukan secara online melalui lembaga arbitrase belum dilaksanakan secara menyeluruh. Suatu proses pemeriksaan dikatakan menyeluruh apabila seluruh proses dilakukan secara online, mulai dari pemilihan lembaga yang khusus menyediakan jasa Online Alternative Dispute Resolution, perjanjian arbitrase, prosedur beracara, hingga penyampaian putusan dilakukan secara online pula. Undang-undang Nomor 30 tahun 1999 tentang Arbitrase dan Alternatif Penyelesaian Sengketa memberikan kemungkinan dipergunakannya e-mail dalam proses penyelesaian sengketa, sekalipun baru dalam tahap penyampaian surat. Hal ini dapat dilihat pada Pasal 4 Ayat (3) Undang-undang Nomor 30 Tahun 1999 Tentang Arbitrase dan Alternatif Penyelesaian Sengketa yang berbunyi: "Dalam hal disepakati penyelesaian sengketa melalui arbitrase terjadi dalam bentuk pertukaran surat, maka pengiriman teleks, telegram, faksimili, e-mail atau dalam bentuk sarana komunikasi lainnya, wajib disertai dengan suatu catatan penerimaan oleh para pihak." Dalam hal sengketa konsumen e-commerce terjadi di Indonesia, 
konsumen dapat memanfaatkan peran Badan Penyelesaian Sengketa Konsumen (BPSK).

Apabila mencermati peraturan yang mengatur tentang gugatan dalam sengketa konsumen, maka dapat dikatakan bahwa penyelesaian sengketa melalui BPSK akan lebih cepat dibandingkan apabila sengketa tersebut dibawa ke jalur litigasi (pengadilan). Meskipun sifat putusan yang mengikat dan final BPSK pada teorinya dapat diajukan ke Pengadilan Negeri dan MA. Dalam transaksi $e$ commerce, posisi BPSK sebagai badan yang memfasilitasi penyeleseaian sengketa konsumen menjadi perhatian serius.

Pelaksanaan arbitrase online di Indonesia telah sesuai dan tidak bertentangan dengan peraturan perundang-undangan yang ada, khususnya Undang-undang Nomor 30 Tahun 1999. Meskipun, dasar hukum pelaksanaan arbitrase online telah ada, permasalahannya adalah tidak ada aturan pelaksanaan yang mengatur bagaimana arbitrase online itu dijalankan. Apabila pengaturan pelaksanaan arbitrase online diserahkan kepada para pihak untuk mengaturnya sendiri, dikhawatirkan tidak ada standar yang baku tentang pelaksanaan arbitrase online yang efektif dan efisien (Paulinus Siburian 2004: 124). Selain tidak adanya aturan pelaksanaan mengenai arbitrase online, hambatan terbesar pelaksanaan arbitrase online di Indonesia menyangkut sarana dan prasarana arbitrase online.

Prosedur pelaksanaan arbitrase online sama dengan pelaksanaan arbitrase konvensional. Dengan terselesaikannya konflik ataupun sengketa yang terjadi antara pelaku usaha dan konsumen dalam perdagangan melalui media elektronik dengan cara penyelesaian sengketa melalui cyber arbitration menjamin berfungsinya norma-norma yang berlaku dalam masyarakat, sehingga terciptalah penegakan hukum dalam perdagangan melalui media elektronik. Penegakan hukum perlindungan konsumen dalam perdagangan elektronik dapat tercipta saat terselesaikannya sengketa yang terjadi antara pelaku usaha dan konsumen. Perlindungan konsumen menjamin adanya kepastian hukum bagi konsumen yang merasa dirugikan sehingga dapat terwujud tujuan perlindungan konsumen, jika terjadi sengketa atau konflik antar pelaku usaha dan konsumen maka dapat diselesaikan melalui: 
1) Pengadilan (Litigasi)

2) Non Litigasi, yaitu dengan cara mengajukan gugatan melalui BPSK (Badan Penyelesaian Sengketa Konsumen), melalui BPSK dapat ditempuh melalui 2 cara yaitu : Mediasi dan Arbitrase.

Perdagangan elektronik, jika terjadi sengketa ataupun konflik antara pelaku usaha dan konsumen maka dapat ditempuh juga dengan kedua cara tersebut diatas, tetapi dalam penyelesaian sengketa dengan jalan Non Litigasi, lembaga arbitrase yang dipilih adalah arbitrase cyber, dimana secara umum lembaga arbitrase dalam perdagangan konvensional dan perdagangan elektronik adalah sama tetapi perbedaannya adalah prosedur pelaksanaan dalam penyelesaian sengketa elektronik dilakukan melalui dunia maya, pelaksanaan penyelesaian sengketanya dilakukan melalui media elektronik. Para pihak dapat menyelesaikan sengketa melalui lembaga arbitrase (dalam hal ini cyber arbitration) yang sifat putusannya final dan binding.

\section{Simpulan dan Saran}

\section{Simpulan}

Perlindungan konsumen menjamin adanya kepastian hukum bagi konsumen yang merasa dirugikan sehingga dapat terwujud tujuan perlindungan konsumen, jika terjadi sengketa atau konflik antar pelaku usaha dan konsumen maka dapat diselesaikan melalui: Litigasi dan Non litigasi.

Perdagangan elektronik merupakan model transaksi dengan karakteristik yang berbeda dengan perdagangan konvensional. Daya jangkaunya tidak hanya local tapi juga bersifat global sehingga dalam tranksaksi elektronik atau $e$ commerce jika terdapat permasalahan maka dapat menggunakan instrument undang-undang Informasi dan Transaksi Elektronik dan Peraturan Pemerintah Nomor 82 Tahun 2012 Tentang Penyelenggaraan Sitem dan Transaksi Elektronik.

\section{Saran}

Berdasarkan simpulan di atas, maka disarankan bagi masyarakat sebaiknya selektif dalam melakukan transaksi secara online dan mengedepankan aspek keamanan transaksi dan kehati-hatian sebagai pertimbangan utama dalam 
melakukan transaksi jual beli secara on-line. Bagi pelaku usaha sebaiknya lebih memperhatikan perbuatan yang dilarang sesuai dengan peraturan perundangundangan yang berlaku.

Bagi aparat penegak hukum sebaiknya lebih teliti dalam mengawasi electronic commerce atau dengan kata lain transaksi elektronik sehingga dapat menerapkan ketentuan dalam Undang-undang Nomor 8 Tahun 1999 tentang Perlindungan Konsumen dan Undang-undang Nomor 11 Tahun 2008 tentang Informasi dan Transaksi Elektronik. 


\section{DAFTAR PUSTAKA}

\section{Buku:}

Abdul Kadir Muhammad. 2006. Hukum Perjanjian. Bandung: PT. Citra Aditya Bakti.

Ahmad Ramli, M. 2004. Cyber Law dan HAKI dalam Sistem Hukum di Indonesia. Bandung: Refika Aditama.

Dikdik M. Arief Mansur. 2005. Cyber Law, Aspek Hukum Tekhnologi Informasi. Jakarta: Refika Aditama.

Endang Sri Wahyuni. 2003. Aspek Hukum Sertifikasi dan Keterkaitannya dengan Perlindungan Konsumen. Bandung: PT. Citra Aditya Bakti

Jhonny Ibrahim. 2005. Teori dan Metodologi Penelitian Hukum Normatif. Jakarta: Bayumedia.

Mariam Darus Badrulzaman (dkk). 2001. Kompilasi Hukum Perikatan. Bandung: Citra Aditya Bakti.

Mariam Darus Badrulzaman. 2005. Aneka Hukum Bisnis. Bandung: Alumni.

Nasution. A. Z. 1995. Konsumen dan Hukum. Tinjauan Sosial, Ekonomi dan Hukum pada Perlindungan Konsumen Indonesia. Jakarta: Pustaka Sinar Harapan.

Salim H. S. 2003. Hukum Kontrak Teori dan Teknik Penyusunan Kontrak. Jakarta: Sinar Grafika.

Siburian, Paulinus. 2004. Arbitrase Online (Alternatif Penyelesaian Sengketa Perdagangan Secara Elektronik). Jakarta: Djambatan

\section{Artikel dan Jurnal:}

Ester Dwi Magfirah. "Perlindungan Konsumen dalam E-commerce", www. wordpress com. 25 Februari 2007.

Hukum Positif. "Sengketa Perdagangan Elektronik". www. hukumpositif.com. diakses 5 Maret 2010.

Jun Cai. 2002. Keabsahan Kontrak Elektronik. Medan. Pascasarjana Universitas Sumatera Utara.

Komunitas Akuntan, "E-commerce dan Permasalahannya". www.accounting community. blogspot.com, diakses 5 Maret 2010 
Sirait, Ningrum Natasya. 2008 "Penyelesaian Sengketa di Luar Pengadilan atau Non Litigasi". Bahan Kuliah pada Universitas Sumatera Utara.

Sirait, Ningrum Natasya. 2008. “Aspek Hukum Perjanjian Kontrak Perjanjian Arbitrase". Bahan Kuliah pada Universitas Sumatera Utara.

Teguh Arifi Yadi. "Perlindungan Konsumen E-commerce" http://teguharifiyadi. blogspot.com, diakses 5 Maret 2009.

Wibowo, A. M, "Kerangka Hukum Digital Signature dan Electronic Commerce”. www.geocities.com, diakses 9 September 2009.

\section{Peraturan Perundang-undangan:}

Republik Indonesia, Undang-undang Nomor 8 Tahun 1999 tentang Perlindungan Konsumen.

Republik Indonesia, Undang-undang Nomor 11 tahun 2008 tentang Informasi dan Transaksi Elektronik

Republik Indonesia, Undang-undang Nomor 30 Tahun 1999 tentang Arbitrase dan Alternatif Penyelesaian Sengketa 


\section{BIODATA PENULIS}

$\begin{array}{ll}\text { Nama } & \text { : Rizka Syafriana } \\ \text { Pekerjaan } & \text { : Dosen Fakultas Hukum Universitas Muhammadiyah Sumatera } \\ \text { Jabatan } & :- \\ \text { Nomor HP } & : 081375240374 \\ \text { E-mail } & : \text { rizkasyafriana11@ gmail.com } \\ \text { Alamat Kantor } & : \text { Jalan Kapten Muchtar Basri Nomor } 3 \text { Medan }\end{array}$ 